Cite as: Moro, A, Fink, M., Maresch, D. and Fredriksson, A. (2018) Loan managers' decisions and trust in entrepreneurs in different institutional contexts. Entrepreneurship \& Regional Development 30 (1-2): 146-172.

\title{
Loan Managers' Decisions and Trust in Entrepreneurs in Different Institutional Contexts
}

\author{
Andrea Moro, Cranfield School of Management, Cranfield University, andrea.moro@cranfield.ac.uk \\ Matthias Fink, Anglia Ruskin University Cambridge, matthias.fink@anglia.ac.uk \\ Daniela Maresch, Institute for Innovation Management, JKU Johannes Kepler University \\ daniela.maresch@jku.at \\ Antti Fredriksson, Turku School of Economics, antti.fredriksson@utu.fi
}

\begin{abstract}
Loan managers' trust in entrepreneurs can be a useful tool for overcoming entrepreneurial firms' opaqueness. Nevertheless, the possibility for loan managers to leverage trust can be affected by differences in the regulative institutions within the banks (type of bank) and by place-bound normative institutions (social context). By relying on semistructured interviews and a survey of 450 bank-entrepreneur relationships, this study finds that a positive impact of trust in lending relationships is sensitive to different place-bound normative institutions and to the regulative institutions within the banks. The results are robust with respect to potential endogeneity issues.
\end{abstract}

Key words: Bank Credit, Relationship Lending, Small and Medium Enterprises, Trust, Institutional Embeddedness.

\section{Introduction}

Entrepreneurial firms face major issues in fulfilling their financial needs (Ang 1992). Often, their access to additional equity from their current shareholders is constrained because 
the latter tend to invest their entire wealth in the venture from the very beginning (Ang et al. 1995; Avery et al. 1998). Additionally, entrepreneurs are reluctant to raise external equity, since it may reduce their freedom in managing the firm, it limits non-pecuniary benefits, and it implies the implementation of additional control and management tools (Hamilton 2000; Moskowitz and Vissing-Jørgensen 2002). Thus, entrepreneurs tend to rely on banks, which grant them the credit they need for survival and the development of entrepreneurial ventures (Cassar 2004; de Bettignies and Brander 2007).

Interestingly, the term credit derives from the Latin creditum, the past participle of the Latin verb credere, which means to believe, to trust, but also to provide credit (Morwood 2005). Indeed, when taking a lending decision, what underpins the loan manager's analysis of the trade-off between risk and return is the assessment of the entrepreneurs' trustworthiness, i.e. their capability and willingness to repay the debt (Howorth and Moro 2006). This holds particularly true when banks lend to entrepreneurial ventures that are characterised by a high level of opaqueness (Berger et al. 2001). The loan manager's perception of the entrepreneurs' trustworthiness is thus a decisive component of the lending decision. In spite of the high practical relevance, surprisingly limited research has been carried out into the role of trust in credit access (Harhoff and Körting 1998; Moro and Fink 2013) and in these studies the effect of the social context of the location in which the lending relationship is embedded is not explored.

Mayer et al. (1995) argue that there is no such thing as a given disposition to trust and prominent researchers have recently called for putting trust research back into its institutional context (Bachman 2011; Bachman and Inkpen 2011), more specifically into the institutional context of regions (Fink and Harms 2012; Welter 2011). They criticise mainstream research on trust (focusing on a micro perspective) for not fully accounting for the complexity of social interaction and its disregard of the actors' embeddedness in the 
institutional environment (Fink and Harms 2012; Welter et al. 2004; Welter and Kautonen 2005). In fact, several studies highlight the relationship between cultural-cognitive elements of institutions and trust, pointing out that culture affects norms, values and underlying behavioural assumptions that, in turn, influence trust perception and use via cognitive processes (Doney et al. 1998). In addition, earlier research also suggests that trust formation and development are affected by the social interactions that are embedded in the institutional context (Oba and Semerciöz 2005), which differs across different relationships, places and points in time (Jones and George 1998; Meccheri and Pelloni 2006). Interestingly, the role of the institutional context is also addressed by research in finance. The role of national as well as local culture, which can be understood as aspects of the institutional context, is stressed by the works of Bellucci et al. (2010), Degryse and Ongena (2002), Greenman (2013) and Zheng et al. (2012). Moreover, earlier research in this field also points out the key role of the regulative institutional context in which financing relationships are embedded (Beck et al. 2003; Haselmann and Wachtel 2010; Moro et al. 2016).

All in all, it is mandatory to move to a holistic approach that enables researchers to gain a realistic understanding of the role of trust embedded in relationships, and thus to formulate relevant statements for the specific situation being investigated. With a more realistic view on trust the dark side of trust ( Kautonen et al. 2010) and its implications for lending relationships also becomes more visible. Earlier research highlighted that, besides its favourable aspects, trust also brings about a threat of manipulation (McEvily and Tortoriello 2011) and the resulting risk of being blind to changing circumstances (Patzelt and Shepherd 2008; Thorgren and Wincent 2011). Trust was also found to reduce scepticism (Kahneman et al. 1982), which may lead to reduced monitoring (Williams 2001) and enhanced risk of fraud (Shapiro 1987).

This study investigates the role of trust in lending relationships from a perspective 
that considers the institutional context. Following the call of Moro and Fink (2013), it investigates the effect of loan managers' trust in their entrepreneurial clients on the amount of overall credit provided to entrepreneurial firms, by focusing explicitly on the institutional context in which the lending relationship is embedded. The research investigates the role of trust in established relationships only, for the following reasons. First, as trust develops over time, loan managers have very little room for exploiting trust when no previous relationship exists. In this case, they can only rely on trust if they have had the opportunity to develop it outside of the business relationship. Second, banks do not have data about potential customers who decided not to apply for a loan. Even in the case of potential customers who were refused loans, banks have very little data and loan managers would struggle to complete our survey, since they are likely to remember very little about customers they turned down.

As called for by Molina-Azorín et al. (2012), the methodological approach relies on a mixed-methods strategy. We employ a cross-case content analysis of the transcripts of narrative interviews with loan managers (i) to investigate the impact of the loan manager's trust in the entrepreneur on the credit amount granted and (ii) to identify place-bound social norms and size-related regulations within the banks as the two aspects of the institutional context in which the lending relationship is embedded. The findings of the qualitative study are compared against the backdrop of the findings from the current literature to develop hypotheses that are subsequently tested using regression analysis, based on 450 observations collected at nine banks in the Italian regions of Friuli and South Tyrol.

We find that, when reintegrated into the institutional context, the positive impact of loan managers' trust in their entrepreneurial clients on credit access is sensitive to different place-bound normative institutions: while cultural institutions in South Tyrol foster the role of trust in providing credit to entrepreneurial firms, they do not support it in Friuli. Thus, it is relevant where your firm operates and applies for loans. We also find that the positive effect 
of trust on credit access is sensitive to size-related differences in the regulative institutions within the banks: while in smaller banks regulative institutions appear to exploit trust as a decision criterion, there is high uncertainty as to whether this is the case in larger banks where the internal regulations and procedures may preclude the bank's possibility to exploit trust. Anecdotal evidence on unfavourable effects of trust on credit access identified in the qualitative data is not reinforced in the quantitative survey.

This research is relevant for banks, entrepreneurs and policy makers. The results highlight that banks and businesses can leverage trust in diverse social settings and places. However, this effect is neither generalisable across different place-based normative institutional settings, nor across different regulative institutional settings (i.e. types of banks). From the banks' perspective, this means that specific types of banks can leverage a trustbased lending strategy in specific types of regional settings. Thus, for small banks where credit decisions are taken close to the customer, trust can represent a competitive advantage vis-à-vis large banks, whose credit decisions are made at a distance within complex organisational structures. Interestingly, this is not only true in tight-knit, closed communities. From the entrepreneurial firms' perspective, dealing with smaller banks that engage in relationship lending can be a way to compensate for their limited ability to provide convincing facts and figures that document their potential future performance. In practice, such strategy requires the entrepreneurs to be frank and open with their loan manager to build a trusting relationship. In addition, policymakers need to consider the power of social mechanisms, such as trust, as safeguards for behavioural risks in lending transactions when they develop regulations. However, even if on average trust-based lending strategies pay in some regional institutional contexts, both entrepreneurs as well as banks should keep in mind that such strategies also bring about threats such as lock-in effects, over-reliance and late acknowledgement of changes in circumstances that should be considered in each individual 
case.

The remainder of the paper is structured as follows. Section 2 illustrates the conceptual framework on which our research is based. Section 3 describes the methodology and presents the findings of the qualitative study (formulation of hypotheses) and the quantitative study (testing of hypotheses). Section 4 discusses and comments on the findings. Section 5 concludes.

\section{Theoretical Framework}

In view of this study's aim, we will first explain how financial institutions behave and why trust can be relevant for them. Secondly, we will explore the institutional embeddedness of trust and how it affects financing decisions.

Entrepreneurial firms often experience difficulties in obtaining sufficient credit funding. Previous research suggests that this problem arises due to information asymmetries (Diamond 1984). The limited quantity and quality of information publicly available makes it difficult for banks to assess entrepreneurial firms' creditworthiness. To ensure the repayment of the loan, banks can therefore either try to find ways to obtain additional, reliable information, which enables them to make a sound lending decision (Moro et al. 2015), or resort to coercive means, such as covenants or collateral (Berger and Udell 1995; Moro et al. 2014). Yet, coercive means carry considerable transaction costs, which make it difficult for entrepreneurial firms to fulfil them. Consequently, it is decisive for banks to acquire information.

Traditionally, banks base their risk evaluation on available factual and public information, which is collected independently from the relationship between the bank and the entrepreneurial firm ('transaction lending'). However, due to concerns about the quality and the quantity of such information banks often aim at acquiring private information, which is 
derived over time through contact with the entrepreneurial firm, its entrepreneur(s), and its community ('relationship lending') (Berger and Udell 2006). Such information is often subjective and difficult to credibly communicate inside the bank (Stein 2002). Thus, the bank should grant the respective loan manager flexibility and discretion for taking lending decisions.

The underlying assumption of both transaction lending and relationship lending is that the interests of the bank and the entrepreneur are in conflict. In this thinking, entrepreneurs tend to hide as much information as possible in order to avoid any risk of being creditconstrained because of negative information (Jayaratne and Wolken 1999), or because they are concerned that the bank may leak sensitive information to competitors (Rheinbaben and Ruckes 2004). In turn, the bank tends to exploit the intensity and strength of the relationship in order to increase the amount of information the loan manager can access and, thus, its capability to properly evaluate the creditworthiness of the entrepreneur (Howorth et al. 2003; Sharpe 1990). Both issues are linked to the intentions of the entrepreneur, which remain opaque to the loan manager until they are translated into observable action (Ajzen 1991).

In entrepreneurial firm-bank relationships information asymmetry can only be dismissed as a major potential problem when the loan manager perceives the entrepreneur as trustworthy (Luhmann 2000; Mayer et al. 1995; Ring and Van de Ven 1992), that is, as someone who takes into consideration the interests of others (perceived benevolence), and has high levels of commitment to the same norms and values as the loan manager (perceived integrity). This insight moves interpersonal trust-based relationships (Nooteboom 2002) to the centre of attention of this research.

There are different forms of interpersonal trust (for an overview, see Li 2007). The strongest form of interpersonal trust is identification-based trust, which implies identification with the values and standards of behaviour of the interaction partner (Lewicki and Bunker 
1996; McAllister 1995). A psychological contract that is based on the self-commitment of the interaction partners (Fink and Kessler 2010) replaces formal contractual safeguards (Barney and Hansen 1994; Ring and Van de Ven 1992). It is this level of trust that is required in the lending relationship to allow the loan manager to dismiss information asymmetry in a given customer relationship.

With the psychological contract, actors make themselves dependent on their interaction partners' future and thus contingent behaviour. We therefore define trust, in line with Mayer et al. (1995), as "the willingness of a party to be vulnerable to the actions of another party based on the expectation that the other will perform a particular action important to the trustor, irrespective of the ability to monitor or control that other party" (ibid. p. 712).

The step into a state of vulnerability to the contingent behaviour of the other, which Möllering (2001) called a "leap of faith", is seen as the starting point of identification-based trust (Lewicki and Bunker 1996; Nooteboom 2002). Entrepreneurs who provide sensitive information to the loan manager take such a leap of faith. At the same time, in relationship lending loan managers provide loans to entrepreneurs, even if there is not enough factual and public information to fully justify their decision in the first place. With this risky advance performance, they also take a leap of faith. In lending relationships, the power of trust begins where facts and figures end. Such leaps of faith require a trustor to perceive trustees as trustworthy ( Kautonen et al. 2010). According to Mayer et al. (1995), trustworthiness is based on three factors - ability, benevolence, and integrity. The level of interpersonal trust depends on the strength of those three factors. Ability looks at aspects such as skills and competence. It is domain-specific and cannot necessarily be generalised to other situations. Benevolence is the extent to which a trustee is believed to voluntarily do good for the trusting party, and is relationship-specific. "Integrity is the trustor's perception that the trustee adheres 
to a set of principles considered acceptable to the trustor" (Mayer et al. 1995, 729). Thus, the perception of trustworthiness requires that the loan manager has knowledge of the entrepreneur.

However, the source of this knowledge does not necessarily lie within the professional customer relationship, but can also be rooted in the social context in which both entrepreneur and loan manager are embedded. This is because the interpersonal relationship and trust between loan managers and entrepreneurs do not evolve and develop in a vacuum. Rather, as social individuals, loan managers and entrepreneurs are embedded in the close-knit fabric of social relationships. Through this social embeddedness individuals face institutions that shape their perceptions and behaviour (Johnston and Selsky 2006; Mathews and Stokes 2013). For Scott (1995) institutions are: “[...] social structures that have attained a high degree of resilience. [They] are composed of cultural-cognitive, normative, and regulative elements that, together with associated activities and resources, provide stability and meaning to social life. Institutions are transmitted by various types of carriers, including symbolic systems, relational systems, routines and artefacts" (ibid. p. 33). Garud et al. (2007) characterise these cultural-cognitive, normative and regulative elements of institutions as follows: "the regulative [...] guides action through coercion and threat of formal sanction; the normative [...] guides action through norms of acceptability, morality and ethics; and the cognitive guides action through the very categories and frames by which actors know and interpret their world" (ibid. p. 958). Sociological institutionalism highlights that social identity and the meanings individuals attribute to economic practices have to be taken into account in order to understand their behaviour (Jepperson 1991; Meyer and Rowan 1977). Meaning is collectively constructed through the social interactions of individuals who thereby create common points of reference for their identities, actions and relationships (Berger and Luckmann 1967; Greenman 2013; Scott 1995). As intentions are formed and translated into 
action with institutions in play, the behaviour of individuals may not be characterised as purely individual but rather as embedded agency (DiMaggio and Powell 1991). This notion highlights the interplay of individuals and institutions in the genesis of action as the observable result of the intention.

Also in lending relationships, loan managers and entrepreneurs constantly construct joint meanings of their perceptions and actions against the background of the specific institutional embedding in their interactions. These interpretations of their own and the interaction partner's identities and actions can differ from the meanings constructed at the societal level. Thus, we focus on the relationship between the loan manager and the entrepreneur as the unit of analysis. More specifically, we account for the institutional embeddedness of the social phenomenon of trust by investigating the impact of regulative and normative institutions on the power of trust for determining credit access in lending relationships. We concentrate on identification-based interpersonal trust within our unit of analysis (i.e. the relationship between loan manager and entrepreneur), because following the concept of embedded agency the institutional setting is reflected in the construction of meaning of their life-world within the interaction between loan manager and entrepreneur and is therefore accounted for when the individual actors form their intentions (Berger and Luckmann 1967). Trust on other levels as the interpersonal relationship and trust that is directed at subjects or objects other than the interaction partner therefore have to be interpreted as part of the institutional setting.

\section{Empirical Work: A Mixed-Methods Approach}

We used a sequential mixed-methods research strategy to investigate the empirical relevance of the effects of trust and the institutional context on credit access, which allowed for triangulation between and within the method types (Creswell and Plano Clark 2007; 
Denzin 1978). Firstly, employing content analysis of narrative interviews with loan managers in a qualitative study, the core constructs of the argument were condensed and an understanding of the relationships between these constructs was identified. The findings of the qualitative study were then triangulated within the interviews and compared to the findings of previous studies to develop empirically testable hypotheses. Secondly, data were collected through a survey among loan managers to empirically test these hypotheses. Finally, the main findings were triangulated between the qualitative and quantitative approaches to enhance the degree of external validity and gain a holistic understanding of the complex phenomenon under study (Jick 1979). In both the qualitative and the quantitative analysis, the unit of analysis is the relationship between the loan manager and the respective entrepreneur.

The research was conducted in South Tyrol and Friuli, two areas in north-east Italy. Both areas are considered rich in terms of their contributions to the Italian GDP and are characterised by many entrepreneurial firms, sometimes grouped into small industrial districts within which expertise and knowledge are easily transferred and shared. However, the two areas also show some differences: South Tyrol, a territory of 7,400 square kilometres and approximately 520,000 inhabitants with the capital Bozen and 116 municipalities, borders on Austria and was a part of Austria until 1920. 62 per cent of South Tyrol's population belongs to the German linguistic group. Its roots lie mainly in German culture and traditions. In fact, the area is culturally and linguistically a small German enclave in Italy.

Friuli spans a little over 8,000 square kilometres with a population close to a million inhabitants. Its capital is Udine. It borders on both Austria and Slovenia. In contrast to South Tyrol, this area's culture and traditions are mainly rooted in Italian heritage.

\subsection{Qualitative Study: Towards Hypotheses Rooted in Context}

The first study follows an 'interpretative qualitative' approach (Gephart 2004), 
focusing on the general mechanisms that can be understood through the in-depth analysis of specific situations (Moulaert and Nussbaumer 2005; Ramstad 1986; Sayer 1992). By looking at the narrations of loan managers, we identify core concepts that arise from the generalities within and differences between the specific cases.

Content analysis of the material gathered (Mayring 2008) enables us to condense the concrete meaning of the core concepts and the relationships described in each of the narrations (Moulaert and Nussbaumer 2005). By identifying the cross-case patterns (Eisenhardt 1989) we develop a cross-case understanding of trust and the effects of trust on lending decisions within its institutional embeddedness.

\section{Case Selection and Data Collection}

Data were collected by direct field research, through narrative interviews (Lieblich et al. 1998) with eight loan managers, conducted in 2005 and 2006. In selecting interview partners, we strove towards collecting as diverse a set of perspectives as possible to identify the meanings behind the statements. Thus, we contacted six male and two female loan managers with diverse backgrounds (age, gender, educational background), from three banks in different locations. The interviews were conducted in places other than the interviewees' workplaces to create a relaxed atmosphere. All interviews were audio-recorded and transcribed. This strategy of data collection also allowed us to analyse the data using the principle of case triangulation within the interviewees, enhancing internal consistency and reliability (Yin 2009).

Findings: The Role of Trust in the Loan Managers' Own Words Compared to the Literature

As already discussed, trust is found to play a relevant role in business relationships (Barney and Hansen 1994; McAllister 1995; Friederike Welter 2012), even in financing relationships (Strätling et al. 2013). However, business relationships are also affected by the institutional environment, as it shapes the way in which people interact, what is considered 
relevant to business decisions and how relationships evolve (Scott 2010). From the narrative interviews, two key aspects of the institutional environment arise. Firstly, whether the actors are located in South Tyrol or Friuli reflects the normative level of the relevant institutional environment. Secondly, the size of the bank reflects the relevant regulative environment of the loan managers.

The insight that institutions are anchored in a specific place introduces a geographical scale to this theoretical approach (Friederike Welter and Trettin 2011). The perceptions and behaviour of economic actors are partly rooted in the local context (Bosma and Schutjens 2011; Jennings et al. 2013). Thornton and Flynn (2003) show that economic practice is affected by the social boundaries of local communities, reflecting local norms and shared meanings. Sociological institutionalists stress the role of the interrelation between the social identity and norms prevailing in a specific place as factors that influence economic activity (Healey 2002; Richardson and Jensen 2003). Both Lang et al. (2013) and Kibler et al. (2015) highlight the role of place in institutional analyses in entrepreneurship research.

In terms of normative institutions, South Tyrol is quite different to the rest of Italy. A good knowledge of German is important for working in the area and this affects the mobility of people from other parts of Italy. This fact has supported the development of a strong local community where everyone tends to know everyone else. Tight communities have been found to facilitate the development of trust (Tillmar 2006). In contrast, there is no linguistic barrier in Friuli: mobility is quite high and the communities are more open. As a consequence, it is not particularly unexpected that we can find several differences between the two areas regarding the institutional embeddedness of lending relationships. The role played by the social norms prevailing within the community seems to be more relevant in South Tyrol than in Friuli. This could be due to several reasons. Firstly, the higher mobility in Friuli ("The local community faces a relatively high turnover and many customers are quite 
new to the area") might adversely affect the chance that a loan manager will develop a strong relationship with a customer ("In the last ten years a lot of new people have moved in. You can meet only a fraction of them at Sunday mass or at the local Red Cross branch"), which, in turn, would help trust development (Burt and Knez 1996; Lewicki and Wiethoff 2000). In fact, the higher mobility implies that loan managers in Friuli are not as able to interact properly with customers to develop trust ("I wish I could trust my customers more but sometimes they are totally new to me and to the area: how can I trust them?") as their colleagues in South Tyrol ("I have known the large majority of the population in the area since I was a child"). Thus, what appears to emerge is that loan managers in Friuli are more negative about their ability to use trust than their counterparts in South Tyrol. Secondly, loan managers are less strongly linked to the local community in Friuli and may therefore be unable to appreciate the entrepreneurs' community involvement, a behaviour that demonstrates shared social norms. In contrast to the situation in South Tyrol, it is quite common for loan managers in Friuli to live outside the area where they work ("I spend my entire working day here but I live in a town 45 kilometres away. I guess I miss some relevant information about what happens around here"). Thus, compared to loan managers in Friuli, South Tyrolean loan managers adhere more strongly to the locally rooted social norms. Thirdly, loan managers tend to move from one branch to another more frequently in Friuli than in South Tyrol. Higher mobility affects the loan managers' chances of developing longlasting relationships, as suggested by Scott (2006). All in all, differences in the regionally rooted normative institutional environment can affect loan managers' ability to fully leverage trust, with Friuli at a disadvantage in comparison to South Tyrol. We therefore propose the following hypothesis:

H1: The positive effect of a loan manager's trust in an entrepreneur on the 
overall amount of credit granted is sensitive to the normative institutional environment prevailing in the place.

Previous literature stresses that larger and smaller banks deal with customers differently (Berger et al. 2005): smaller banks are more likely to base their lending decision on private information than larger banks and to lend to small and entrepreneurial firms. The narrative interviews support these findings. We find that loan managers of smaller banks tend to exploit information over and above the information provided in annual financial statements and interim financial reports, which was sometimes considered unreliable: "I do not rely on official facts and figures. You know they are affected by tax strategy: asset value, work in progress, inventory - all rubbish. They are always adjusted. You know there are costs and revenues that are not recorded in the books. Entrepreneurs disclose them if you exert some pressure but you have no proof". In addition, the loan managers of the small banks tended to stress the importance of accessing information from other sources, such as other customers ("You gain information about your client from other customers. They inform you about whether he is honest in his business relationships, his capabilities, etc."), and told us that they exploit such information: "I have a lot of room for manoeuvre. In addition, when I cannot decide whether to give credit, I can always discuss things face-to-face with whoever is in charge of making the decision". Thus, loan managers could exploit the trust they had in the customer, or transfer their evaluation of such trust to whoever is responsible for making the decision ("I typically share my opinions about the customer with the director"). In contrast, larger banks tended to rely on credit scoring systems (Berger and Udell 2006), which reduced the loan managers' room for manoeuvre ("The credit scoring system decides whether we will provide credit to the customer") (Scott 2006).

In addition, the layers of command are more complex and articulated in larger banks 
(Berger and Udell 2002), which increases the difficulty for the loan manager to transfer his/her personal opinion to whoever is in charge of making the decision ("For larger amounts, the decision is taken centrally. I have to send out all the documents but I do not know who is in charge of taking the decision"). Thus, the findings from the narrative interviews suggest that differences in the regulative institutional environment related to the size of the bank can affect the loan managers' ability to leverage trust. Based on these arguments, we formulate the second hypothesis:

H2: The positive effect of the loan manager's trust in the entrepreneur on the overall amount of credit granted is sensitive to the regulative institutional environment prevailing in the banking organisation.

Table 1 reports some quotations from the interviews and the derivation of the hypotheses.

\section{INSERT TABLE 1 HERE}

\subsection{Quantitative Study: Testing the Hypotheses}

\section{Method and Data}

The qualitative study gave us the opportunity to develop hypotheses rooted in the relevant context and in the literature, which we then tested using quantitative data. Nine banks participated in the data collection process between autumn 2005 and early 2007, six in South Tyrol (302 observations) and three in Friuli (148 observations). Together with the banks, the researchers selected a random sample of entrepreneurial firms from the customers of each bank.

The selection process comprised the following steps: first, each bank generated a list 
of small entrepreneurial firms, i.e. businesses with a turnover below $€ 50$ million, with fewer than 250 employees and with less than $€ 43$ million in total on the balance sheet, excluding agricultural firms (European Commission Recommendation 2003/361/EC). Next, the bank sorted these customers, either alphabetically or based on a unique customer identification number. Finally, it picked every $n^{\text {th }}$ customer to be included in the sample. Since both types of sorting are independent of the customers' characteristics and their relationships with the bank, the selection process generated a random sample.

The banks asked their loan managers to fill in a questionnaire in which loan managers were asked to evaluate their level of trust in the entrepreneur. To achieve this, we follow Tinsley (1996)'s critique and adapt Mayer et al. (1995)'s model of trust by dropping the dimension "ability". Trust is, thus, modelled as consisting of the following dimensions: (1) benevolence (i.e. the entrepreneur takes into consideration the interests of others), and (2) integrity (i.e. the entrepreneur is perceived to have high levels of commitment to the same norms and values as the loan manager). As shown in the interviews, benevolence is rooted in experience that has also been gained outside the business relationship. As a match between the interaction partners' maxims, integrity is also independent of any information about the performance of the firm. When it comes to scale construction, we carefully selected items for measuring benevolence and integrity by relying on previous scales (Cummings and Bromiley 1996; Mayer and Davies 1999). We pre-tested them by asking a group of loan managers, who were not involved in the later data collection, to fill in the survey and provide us with detailed feedback about the items. Two of the original items were regarded as vague and too close to other items. Thus, we decided to delete them from our inventory. The result is a list of items that are not affected by the amount of credit or other financial variables (Chenhall and Moers 2007). In addition, the central loan office of each bank provided financial information about these firms from the bank's information system. These information systems contain data 
drawn from the public database maintained by the Italian Chamber of Commerce, which collects data from firms' annual financial reports as well as from the Bank of Italy database (Centrale Rischi), in which the credit provided by banks to each of their customers is recorded and updated monthly.

We ended up with 450 loan manager-entrepreneurial firm relationships. The final sample represents more than $1.5 \%$ of the overall population of entrepreneurial firms with lending relationships in the two areas considered.

The analysis was carried out using STATA version 12. Factor analysis was employed to test whether a "trust" factor could be derived from the vector of items measuring the loan managers' perceived benevolence and integrity of the entrepreneurs. We then tested the hypotheses by regressing the independent variables and the control variables against the overall amount of credit gained. The process was repeated for the sub-samples that depict the different institutional settings. Since standard ordinary least square regressions present issues linked to heteroscedasticity, the regressions were estimated using ordinary least squares with robust estimation of standard error.

\section{The Variables}

Before illustrating and commenting on the results of the regression, we will briefly explain the variables used.

Dependent Variable - Overall Amount of Credit: In contrast to previous studies on trust in lending relationships, which use the cost of credit or short-term credit as dependent variables (Harhoff and Körting 1998; Moro and Fink 2013), we use the overall amount of credit for the following reasons. First, if trust is as relevant as is suggested by our interviews, its role should be pervasive and therefore affect both long and short-term credit. Thus, by using the overall amount of credit, we approach the analysis of trust in a more conservative way. Secondly, cultural and social aspects are subject to short and long-term changes. Whereas 
short-term changes mainly affect short-term credit decisions, historical social and cultural elements mainly affect long-term credit decisions. By looking at the overall amount of credit, we can take into consideration the impact of both short and long-term cultural and social changes on the credit obtained. Lastly, long-term debt is used for committed investments that are expected to generate profits for several years, whereas short-term debt is used for cash management or related activities that are mainly used for operative purposes only.

To account for the fact that the variable is right skewed, we used the logarithm of the total debt (LN_TOTAL_DEBT). The original value is expressed in Euros.

Independent Variables: The survey instrument measures the loan manager's perception of identification-based interpersonal trust in the entrepreneur according to a vector of six items. Each item is based on previous inventories (Cummings and Bromiley 1996; Jarvenpaa et al. 1998; Muthusamy and White 2005), measuring the willingness to take a counterpart's interests into consideration (benevolence) and the ethical assumptions behind people's behaviour (integrity). Each item was critically evaluated and pre-tested. The loan managers evaluated the individual items on a 5-point Likert scale ranging from 'totally disagree' (1) to 'totally agree' (5), except for the last item, where the responses ranged from 'I strongly advise against' (1) to 'I strongly advise in favour' (5). The mode is 4 ('I partially agree') for all items, except for "The entrepreneur pays attention to the needs of his/her employees" and "The entrepreneur is very involved in the community" for which the mode is 3 ('neither agree nor disagree', representing the neutral response). The averages for the items range from 3.08 ("The entrepreneur is very involved in the community") to 3.87 ("The entrepreneur is totally honest in negotiations with commercial partners").

Multivariate analysis showed that the item "The entrepreneur is very involved in the community" had low communality and we therefore dropped it from the principal components analysis (PCA). Thus, PCA was run on five items, resulting in a Cronbach's 
alpha of 0.8027 , above the benchmarks suggested by Nunnally (1967). The first factor explains $56.82 \%$ of the variance and is the only one with an eigenvalue greater than 1

(2.8410). Consequently, one factor is extracted and defined as TRUST. All the variables load at 0.7226 or more on the single component (the lowest is "The entrepreneur pays attention to the needs of the employees"). The Kaiser-Meyer-Olkin test supports the adequacy of the sample (0.8292, above the suggested threshold limit). The scores were saved for inclusion in the regression analysis. Table 2 reports the descriptive statistics for each item and the results of the factor analysis.

\section{INSERT TABLE 2 HERE}

As banks in both areas are monitored by Banca d'Italia and must follow Italian law and Italian banking regulations, any emerging differences between the two regions studied must be ascribed to different normative institutions. To examine the impact of the normative institutions attached to the regions, we therefore used the dummy variable REGION (South Tyrol $=0$, Friuli $=1$ ). Our expectation was that the dummy variable will be significant, if differences between the areas exist: if the normative institutional context in Friuli/South Tyrol is more supportive of credit access, the variable will have a positive/negative sign. To have a clearer picture of the impact of the normative institutional context on credit access we also re-ran the regression by splitting the dataset between the two regions. The normative institutional setting in South Tyrol is characterised by an especially strong social cohesion that is rooted in an exceptional civic citizenship fostered by "the awareness and acceptance of the idiosyncratic character of South Tyrolean society, i.e. its bi- or trilingualism, its institutional organisation, and its historical and cultural arrangements" (Medda-Windischer and Carlà 2013, p. 2). Thus, our expectation was that trust would be positive and significant in the South Tyrolean sub-sample, but insignificant in the Friuli sub-sample (H1). 
To tackle the differences in the regulative pillar of the institutional setting, we account for the size of the bank that provides the loan to the entrepreneur. As the dataset contains observations from both large and small banks, we used the dummy variable BANK_SIZE to identify large (1) and small (0) banks. The banks classified as small operate very locally (typically in the municipality where they are headquartered and a few municipalities close to it), have a small number of branches (always less than 15), a very short line of command (the loan manager interacts directly with the general manager of the bank), and make very little use of credit scoring/credit rating tools. The banks classified as large operate at least at the regional level, have a greater number of branches (always more than 50), a more complex line of command (the loan manager does not interact directly with the general manager of the bank), and rely more on credit scoring/credit rating tools, even if they do not exclude the possibility of using private information either. If regulative institutions in large (small) banks are more supportive of credit, this variable will have a positive (negative) sign. To have a clearer picture of the role of trust in credit access in different size-related regulative institutional contexts, we re-ran the regression by splitting the dataset into large and small banks. In this case, our expectation was that trust would be positive and significant in small banks and not significant in large banks $(\mathrm{H} 2)$.

Control Variables: A set of control variables was included in the regressions to control for the economic environment, firm characteristics, and the characteristics of the relationship between the loan manager and the entrepreneur. To control for the economic environment, we used the Bank Lending Survey quarterly index (CL_INDEX) provided by the Bank of Italy, which takes values between -1 (a relaxed approach to providing credit to customers) and +1 (a rigid approach to providing credit to customers). To control for firm characteristics, we used the firm's (log of) annual turnover (LN_TURNOVER), with the original value expressed in Euros, the firm's return on sales (ROS = EBIT/Sales), the firm's 
assets turnover (ASS/TURN), and whether the loan is collateralised with firm collateral (FIRM_COLL) and/or personal collateral (PERS_COLL). Finally, to control for the relationship's characteristics, we used the (log of the) length of the relationship (LN_LENGTH) between the bank and the firm, expressed in years, the number of people involved in the relationship at the bank level (BANK_EMP), the frequency with which the loan manager meets the firm (FREQ_MEET), and the frequency with which the credit is reviewed (FREQ_REV). It is important to point out that the length of the relationship is a dimension that is completely different from TRUST. This is because TRUST is based on personal evaluation, while the length of the relationship represents a fact. Further, on the logical level, the dimensions of TRUST are not linked to time, since they are rooted in the interaction partners' norms, values and maxims, which are robust against time.

Table 3 reports descriptive statistics for the variables.

INSERT TABLE 3 HERE 


\subsection{Findings from Testing the Hypotheses}

We present three sets of regressions. The first set of regressions shows the findings for the overall sample, using both trust and the interaction between trust and region and trust and bank size respectively as independent variables. These regressions investigate the role of trust, place-bound social norms (normative institutions), and size-related regulations (regulative institutions) on the overall amount of credit. The second set of regressions aims at testing $\mathrm{H} 1$ and presents the results of the sub-samples for the different regions (South Tyrol/Friuli - different normative institutions). The third set of regressions aims at testing H2 and presents the results of the sub-samples for different bank sizes (large/small banks different regulative institutions).

The regressions present some problems with heteroscedasticity, as the BreuschPagan/Cook-Weisberg test for heteroscedasticity for the regression that includes all the covariates has a $p=0.0848$. Thus, the standard errors are produced using robust estimation. Table 4 reports the regressions that investigate the impact of trust, region and bank size on the overall amount of credit obtained.

\section{INSERT TABLE 4 HERE}

The highest variance inflation factor (VIF) and the average VIF of each regression are reported in the table. No regression has a VIF higher than 10 and all average VIFs are very low, suggesting there are no problems with multicollinearity.

The parsimonious version of the first regression is significant and has an $\mathrm{R}^{2}$ of 0.4245 . This regression does not present problems of multicollinearity (highest VIF - REGION: 3.92; mean VIF: 1.76$)$. TRUST is significant at $p<0.01$ and is positively related to the overall amount of credit obtained. REGION is significant at $p<0.05$ and has a negative sign, indicating that the overall amount of credit obtained is lower among entrepreneurial firms in 
Friuli. This finding tends to support our hypothesis that regional differences in normative institutions affect entrepreneurial firms' credit access. BANK_SIZE is significant at $p<0.01$ and has a negative sign, indicating that the overall amount of credit obtained is lower in entrepreneurial firms that borrow from large banks. This finding tends to support our hypothesis that differences in regulative institutions between large and small banks impact on their lending practices. All in all, the regressions provide initial support for the argument that the size-related regulative institutions and the regionally rooted normative institutions affect the amount of credit obtained by entrepreneurial firms.

To implement a first test for $\mathrm{H} 1$ and $\mathrm{H} 2$ we estimate the original regression including the interaction between trust-region and trust-bank size. The regression is significant and has an $\mathrm{R}^{2}$ of 0.4248 . No changes emerge in the sign and significance level of the covariates. Interestingly, TRUST is significant at $p<.05$, whereas the interactions between trust and region (Friuli = 1) and trust and bank size (large bank =1) are not. This finding suggests that trust is not relevant in large banks and in Friuli (the interaction variables), while it is relevant and impacts on the overall amount of credit obtained in small banks and in South Tyrol. Initially, both $\mathrm{H} 1$ and $\mathrm{H} 2$ thus seem to be supported.

To have a more detailed insight into the role of trust on credit access in different regions and differently sized banks, we re-estimate the regressions on the split dataset.

To test $\mathrm{H} 1$ we first look for differences in the normative institutional environments between the two regional sub-samples South Tyrol and Friuli. We ran a t-test on the dependent variable, the length of the relationship, and turnover. No differences emerge at $p<0.01$ for either the overall amount of credit obtained or turnover, but the lengths of the relationship differ significantly. Whereas the average length of the relationship is 12.03 years in South Tyrol, it is 6.87 years in Friuli. There is no significant difference in the level of TRUST between the two samples $(p<0.01)$, although trust seems to be slightly higher in 
South Tyrol (average 0.128 vs. 0.026 in Friuli). This suggests that the loan managers' trust in entrepreneurs is not significantly affected by the local normative institutions.

Second, we re-estimate the regression on the South Tyrolean and Friuli sub-samples. Table 4 reports the results. The regressions have an $\mathrm{R}^{2}$ of 0.4035 (South Tyrol) and 0.5854 (Friuli), and are significant at $p<0.01$. They do not present problems of multicollinearity. Interestingly, the level of TRUST is positively related to the overall amount of credit obtained in both samples, but TRUST is only significant in the South Tyrolean context. Trust hence affects the amount of credit obtained differently according to the local normative institutions. This finding is in line with the result of the regression that considers the interaction of trust with the region and with the qualitative prediction that bank managers in Friuli might find it more difficult to develop and use trust in their lending relationships with firms. The econometric findings therefore provide further support for H1.

Turning our attention to the role of trust in banks of different sizes (H2), we implement a t-test on the dependent variable, the length of the relationship and turnover to verify whether the two sub-samples are similar. No difference emerges at $p<0.01$. Then, we examine whether differences between large and small banks arise regarding the level of loan managers' trust in entrepreneurs. The level of trust is not significantly different between the two sub-samples $(p<0.01)$, although it seems to be slightly higher in large banks (average 0.038 vs. -0.008 in small ones). This finding is very interesting, since it suggests that the loan managers' lending decisions are not affected by the size-related regulative institutional environment in which they work.

Then, we re-estimate the regression using the sub-samples of large and small banks. These regressions have an $\mathrm{R}^{2}$ of 0.3978 (small banks) and 0.5453 (large banks) respectively; are both significant at $p<0.01$; and they do not suffer from any problems with multicollinearity. Our findings show that TRUST is positively related to the overall amount 
of credit in both samples. However, even though TRUST is significant at $p<0.01$ in the case of small banks, it is not significant in the case of large banks. These findings are in line with both the results of the regression that includes the interaction between trust and bank size and the qualitative evidence. $\mathrm{H} 2$ is hence supported. Interestingly, the similar level of trust in entrepreneurs from the loan managers of large and small banks suggests that it is the lending approach used by large banks that constrains the leverage of trust. The very marginal role of trust in the lending process of large banks can only be attributed to large banks' reluctance to allow loan managers to exploit the trust they have in their entrepreneurial customers, as it cannot be attributed to different trust evaluations being made by the loan managers of large and small banks. This finding supports what emerged in the interviews. In contrast to loan managers of small banks, loan managers of large banks emphasised that their relationships with entrepreneurs were more impersonal and that lending decisions were based on financial information.

\section{Robustness Checks - Endogeneity}

It could be argued that our analysis suffers from endogeneity: by measuring trust we might in fact measure something else, namely the length of the relationship or the information that the loan manager can access. Since trust needs time to evolve and is also based on the information that the loan manager obtains, such criticism might be correct. To check for this potential issue, we re-estimate our regressions instrumenting trust with the length of the relationship and four variables that measure the level of information provided (namely quality, quantity, timeliness and completeness of the information obtained by the entrepreneurial firm). These four dimensions are measured according to a 5-point Likert-type scale. The results are reported in table 5. 
Interestingly, instrumented trust is not significant in any of the regressions, suggesting that by entering trust we are in fact measuring trust and not the length of the relationship or the information accessed by the loan managers. We re-estimate the specification of table 5 including the length of the relationship only (results not reported here), but we do not see a change in the results. Correspondingly, we also include only the four variables that measure the level of information provided (results not reported here). Also in this case, instrumented trust is not significant.

\section{Discussion}

Traditional agency theory suggests that the conflict of interests between the lender (principal) and the borrower (agent) is curbed "ex post" by the development of legal tools (detailed contracts) that align the behaviour of the agent with the behaviour expected by the principal. Interestingly, the suggested mechanisms are not without cost and cannot completely reconcile the agent's and the principal's objectives. One of the negative effects of these tools is that they do not support the development of strong relationships between the contracting parties (Strätling et al. 2013). For example, very stringent contracts and requests for personal collateral can be perceived as excessive intrusiveness by entrepreneurs, reducing their voluntary disclosure of information - labelled passive opportunistic behaviour by Wathne and Heide (2000). Such behaviour by entrepreneurs might reinforce the loan managers' view that they are being provided with partial information of poor quality. It might therefore adversely affect the evaluation of the firm, triggering a more conservative approach to providing credit to it (e.g. refusing new credit, reducing current credit, etc.). All in all, traditional tools can produce a non-cooperative game in which players tend to cheat each other by behaving opportunistically (Axelrod 1981), increasing agency problems instead of reducing them. However, in relationship lending, agency problems can be avoided "ex ante" 
by leveraging trust based on perceived benevolence and integrity. At the same time, the use of control mechanisms and sanctions that banks use to force entrepreneurs to behave in the banks' interests can be reduced, producing savings.

In line with the insights from the qualitative study, our econometric results show a positive effect of loan managers' trust in their entrepreneurial clients on the overall amount of credit granted. Interestingly, the quantitative analysis suggests that this effect is sensitive to both different place-bound normative and size-related regulative institutions. Entrepreneurs who credibly communicate their trustworthiness to loan managers can better bridge the finance gap and survive critical situations. This strategy is more successful with small banks and in areas where the relationship between the loan manager and the entrepreneur is stronger.

The findings support our assumption about the main mechanism underlying the positive effects of interpersonal trust on credit access: relationship lending. As expressed in the label, "relationship lending" is a lending technique that draws on information generated in the loan managers' relationship with the client for the evaluation of the creditworthiness of an entrepreneur. In line with our expectations, close relationships that are commonly found in regions with tight-knit social fabrics breed stronger trust relationships (Medda-Windischer and Carlà 2013) that give access to more information. As a consequence, relationship lending is more effective. However, loan managers need to be granted sufficient leeway in their decision-making power to be able to effectively leverage the information accessed through the social relationships with their clients. We find smaller banks make better use of their relational information base.

The robustness of the trust-credit access relationship might be a result of the historical development of humanistic thinking. Humanity attributes the self-commitment of individuals to a certain set of ethical maxims that developed in Europe and North America during the 
Enlightenment in the $17^{\text {th }}$ and $18^{\text {th }}$ centuries, even if they are rooted in Greek (Aristotle 2012) and Christian (Aquinas 2009) philosophy. However, this stream of philosophy seems to be set aside by economists. They tend to implicitly rely on Hobbes (1651), who argues that the natural state of Man is war of all against all and that civil society was developed to deal with such a state. Hobbes' arguments suggest that Man is inherently selfish, and such selfishness is taken as an assumption by economists such as Friedman (1970). As pillars of perceived trustworthiness, benevolence and integrity are core concepts in humanistic thinking. Benevolence is rooted in the idea that every person is unconditionally valuable (Coleman 2007; Korsgaard 1996). From this value, the norm is derived that interaction partners should be approached in a kind, benevolent way that does not harm them. Integrity is derived from the idea of an individual's autonomy in moral reasoning. Integrity can be described as selfdetermination with regards to maxims, which are in turn shaped by the institutional environment (Fink and Harms 2012; Fink and Kessler 2010). Both concepts - benevolence and integrity - restrict the economic actor in terms of cheating on business partners. Thus, those who build their behaviour on the grounds of humanity are well-equipped to evolve trust-based relationships.

All in all, the empirical results suggest that trust plays an important role in granting entrepreneurs access to credit. A trust-based approach to lending relationships might lower transaction and compliance costs for both parties when they jointly commit to a shared interpretation of their life-world (Berger and Luckmann 1967) and on this shared ground form compatible intentions that translate into favourable sequences of action. This calls for a holistic approach to assessing the embedded agents who interact in the lending relationship over and above the economic dimension, rather than focusing solely on exchanges taking place at a given place at a given point in time. 


\section{Conclusion}

This study is one of the few that addresses the role of trust in lending relationships and the first to consider the institutional embeddedness of trust and its impact on lending relationships. It shows both qualitatively and quantitatively the importance of loan managers' trust in their entrepreneurial customers for credit access, and the role of trust as a tool to mitigate the finance gap entrepreneurial firms face. We find that both the regulative institutions related to the size of the bank and the normative institutions rooted in the place in which the bank is located influence the impact of trust on credit access.

The literature on social capital shows that norms of reciprocity and mutual trust are cornerstones of a functioning economy, as they are prerequisites for collective intentions (Searle 1990; Sugden and Hollis 1993) and for collective action (Grootaert and van Bastelaer 2002; Krishna 2002). Anderson and Jack (2002) elaborated the structural and relational aspects to be dimensions in the process that creates a condition of social capital in an entrepreneurial context. Also, Granovetter (1985) criticises the "undersocialised conception of human behaviour" (p. 483) in the governance approaches of New Institutional Economics, and stresses the fact that, in their behaviour, individuals are strongly influenced by the social context in which they are embedded. All in all, acting according to the norms of humanity is an individual behavioural choice taken within the framework of the institutional environment. Our findings provide another jigsaw piece adding to the empirical evidence supporting the institutional embeddedness of trust-based relationships and their effects, without overcontextualising.

This study examines the role of trust cross-sectionally. To further examine the role of trust in lending relationships it would be beneficial to analyse the topic longitudinally, by exploring how trust evolves over time as the customer's situation changes for the better or for the worse. In addition, this research relies on quite a small dataset and investigates the 
sensitivity of the role of trust to the institutional context along two dimensions only. However, the dataset is large enough to test the generalisability of the insights from the qualitative study across more than one institutional environment, and the selection of the two aspects of the institutional environment studied was not random, but based on the qualitative analysis. The essential role of the context in which trust evolves highlights the importance of replicating the analysis in other institutional contexts to grasp the full impact of the institutional environment on trust perceptions and their effects on lending relationships. Further, as this aspect was not raised by the interviewees, the dark side of trust was not included within the scope of this research. The negative aspects of trust, however, come into play as soon as the collective or individual performance of the trust-based relationship comes under research. While this will be a fruitful next step, as guided by Bachmann, Gillespie and Priem (2015), along the avenue of future research, it was not within the focus of this study. Finally, further research is needed to verify what happens at the beginning of the lending relationship, when loan managers either cannot rely on trust at all (because they do not know the customer) or should exploit trust that has been developed outside their business relationship.

Notwithstanding the limitations, this study indicates that trust plays a more important role in lending relationships than has been acknowledged so far. 


\section{References}

Ajzen, I. (1991). The Theory of Planned Behaviour. Organizational behavior and human decision processes, 50, 179-211.

Anderson, A. R., \& Jack, S. L. (2002). The Articulation of Social Capital in Entrepreneurial Networks: A Glue or a Lubricant? Entrepreneurship \& Regional Development, 14(3), $193-210$.

Ang, J. S. (1992). On the Theory of Finance for Privately Held Firms. Journal of Small Business Finance, 1(3), 185-203.

Ang, J. S., Wuh Lin, J., \& Tyler, F. (1995). Evidence of the Lack of Separation Between Business and Personal Risk Among Small Business. Journal of Small Business Finance, 4(2/3), 197-210.

Aquinas, T. (2009). Summa Teologica. Charleston, SC: BiblioLife LLC.

Aristotle. (2012). The Organon, or Logical Treatises, of Aristotle. Hong Kong: Forgotten Books.

Avery, R. B., Bostic, R. W., \& Samolyk, K. A. (1998). The Role of Personal Wealth in Small Business Finance. Journal of Banking \& Finance, 22(9), 1019-1061.

Axelrod, R. (1981). The Emergence of Cooperation Among Egoists. The American Political Science Review, 75(2), 306-318.

Bachman, R. (2011). At the Crossroads: Future Directions in Trust Research. Journal of Trust Research, 1(2), 203-213.

Bachman, R., \& Inkpen, C. (2011). Understanding Institutional-based Trust Building Processes in Inter-organizational Relationships. Organization Studies, 32(2), 281-301.

Barney, J. B., \& Hansen, M. H. (1994). Trustworthiness as a Source of Competitive Advantage. Strategic Management Journal, 15, 175-190.

Beck, T., Demirgüc-Kunt, A., \& Levin, R. (2003). Law and Finance: Why does Legal Origin 
Matter? Journal of Comparative Economics, 31(4), 653-675.

Bellucci, A., Borisov, A., \& Zazzaro, A. (2010). Does Gender Matter in Bank-Firm

Relationships? Evidence from Small Business Lending. Journal of Banking \& Finance, 34, 2968-2984.

Berger, A. N., Klapper, L. F., \& Udell, G. F. (2001). The Ability of Banks to Lend to Informationally Opaque Small Business. Journal of Banking \& Finance, 25(12), 21272167.

Berger, A. N., Miller, N. H., Petersen, M. A., Rajan, R. G., \& Stein, J. C. (2005). Does Function Follow Organizational Form? Evidence from the Lending Practices of Large and Small Banks. Journal of Financial Economics, 76, 237-269.

Berger, A. N., \& Udell, G. F. (1995). Relationship Lending and the Lines of Credit in Small Firm Finance. Journal of Business, 68(3), 351-381.

Berger, A. N., \& Udell, G. F. (2002). Small Business Credit Availability and Relationship Lending: The Importance of Bank Organisational Structure. The Economic Journal, 112, F35-F53.

Berger, A. N., \& Udell, G. F. (2006). A More Complete Conceptual Framework for SME Finance. Journal of Banking \& Finance, 30(11), 2945-2966.

Berger, P., \& Luckmann, T. (1967). The Social Construction of Reality. A Treatise in the Sociology of Knowledge. New York: Anchor Books.

Bosma, N. S., \& Schutjens, V. (2011). Understanding Regional Variation in Entrepreneurial Activity and Entrepreneurial Attitude in Europe. Annals of Regional Science, 47(3), $711-742$.

Burt, R. S., \& Knez, M. (1996). Trust and Third-Party Gossip. In Trust in Organisations: Frontiers of Theory and Research, edited by R. M. Kramer \& T. R. Tyler, 68-89. Thousands Oaks, CA: SAGE Publications Inc. 
Cassar, G. (2004). The Financing of Business Start-Ups. Journal of Business Venturing, 19(2), 261-283.

Chenhall, R. H., \& Moers, F. (2007). The Issue of Endogeneity within Theory-Based, Quantitative Management Accounting Research. European Accounting Review, 16(1), $173-195$.

Coleman, M. C. (2007). Korsgaard on Kant on the Value of Humanity. The Journal of Value Inquiry, 40, 475-478.

Creswell, J. W., \& Plano Clark, V. L. (2007). Designing and Conducting Mixed Method Research. Thousand Oaks: Sage Publications.

Cummings, L. L., \& Bromiley, P. (1996). The Organisational Trust Inventory (OTI): Development and Validation. In Trust in Organisations: Frontiers of Theory and Research, edited by R. M. Kramer \& T. R. Tyler, 302-330. Thousands Oaks, California: SAGE Publication Inc.

de Bettignies, J.-E., \& Brander, J. A. (2007). Financing Entrepreneurship: Bank Finance Versus Venture Capital. Journal of Business Venturing, 22, 808-832.

Degryse, H., \& Ongena, S. (2002). Bank-Firm Relationships and International Banking Markets. International Journal of the Economics of Business, 9(3), 401-417.

Denzin, N. K. (1978). The Research Act: An Introduction to Sociological Methods. New York: McGraw-Hill.

Diamond, D. W. (1984). Financial Intermediation and Delegated Monitoring. Review of Economic Studies, 51(3), 393-414.

DiMaggio, P. J., \& Powell, W. W. (1991). Introduction. In The New Institutionalism in Organizational Analysis, edited by P. J. DiMaggio \& W. W. Powell, 1-40. London: University of Chicago Press.

Doney, P. M., Cannon, J. P., \& Mullen, M. R. (1998). Understanding the Influence of 
National Culture on the Development of Trust. Academy of Management Review, 23(3), $601-620$.

Eisenhardt, K. M. (1989). Building Theories from Case Study Research. Academy of Management Review, 14(4), 532-550.

Fink, M., \& Harms, R. (2012). Contextualizing the Relationship between Self-Commitment and Performance: Environmental and Behavioural Uncertainty in (Cross-Border) Alliances of SMEs. Entrepreneurship and Regional Development, 24(3-4), 1-19.

Fink, M., \& Kessler, A. (2010). Cooperation, Trust and Performance - Empirical Results from Three Countries. British Journal of Management, 21(2), 469-483.

Friedman, M. (1970). The Social Responsibility of Business is to Increase Its Profit. New York Time Magazine. New York: New York Times Company.

Garud, R., Hardy, C., \& Maguire, S. (2007). Institutional Entrepreneurship as Embedded Agency: An Introduction to the Special Issue. Organization Studies, 28(7), 957-969.

Gephart, R. P. (2004). Qualitative Research and the Academy of Management Journal. Academy of Management Journal, 47(4), 454-462.

Granovetter, M. (1985). Economic Action and Social Structure: The Problem of Embeddedness. American Journal of Sociology, 91(3), 481-510.

Greenman, A. (2013). Everyday Entrepreneurial Action and Cultural Embeddedness: An Institutional Logics Perspective. Entrepreneurship \& Regional Development, 25(7-8), $631-653$.

Grootaert, C., \& van Bastelaer, T. (2002). Social Capital: From Definition to Measurement. In C. Grootaert \& T. van Bastelaer (Eds.), Understanding and Measuring Social Capital. (p. 1-16.). Washington, DC: The World Bank.

Hamilton, B. H. (2000). Does Entrepreneurship Pay? An Empirical Analysis of the Returns to Self-Employment. Journal of Political Economy, 108(3), 604-631. 
Harhoff, D., \& Körting, T. (1998). Lending Relationships in Germany - Empirical Evidence from Survey Data. Journal of Banking \& Finance, 22(10-11), 1317-1353.

Haselmann, R., \& Wachtel, P. (2010). Institutions and Bank Behavior: Legal Environment, Legal Perception and the Composition of Bank Lending. Journal of Money, Credit and Banking, 42, 965-984.

Healey, P. (2002). On Creating the City as a Collective Resource. Urban Studies, 39(10), $1777-1792$.

Hobbes, T. (1651). Leviathan (Vol. 2008). Oxford: Oxford University Press.

Howorth, C., \& Moro, A. (2006). Trust within Entrepreneur Bank Relationships: Insights from Italy. Entrepreneurship Theory and Practice, 30(4), 495-517.

Howorth, C., Peel, M. J., \& Wilson, N. (2003). An Examination of the Factors Associated with Bank Switching in the U.K. Small Firm Sector. Small Business Economics, 20(4), $305-317$.

Jarvenpaa, S. L., Knoll, K., \& Leidner, D. E. (1998). Is Anybody Out There? Antecedents of Trust in Global Virtual Teams. Journal of Management Information Systems, 14(4), 29_ 64.

Jayaratne, J., \& Wolken, J. (1999). How Important are Small Banks to Small Business Lending? New Evidence from a Survey of Small Firms. Journal of Banking \& Finance, $23,427-458$.

Jennings, D., Greenwood, R., Lounsbury, D., \& Suddaby, R. (2013). Institutions, Entrepreneurs, and Communities: A Special Issue on Entrepreneurship. Journal of Business Venturing, 28(1), 1-9.

Jensen, M. C., \& Meckling, W. H. (1976). Theory of the Firm: Managerial Behaviour, Agency Costs, and Ownership Structure. Journal of Financial Economics, 3(4), 305360. 
Jepperson, R. (1991). Institutions, Iinstitutional Effects, and Institutionalism. In The New Institutionalism in Organizational Analysis, edited by W. W. Powell \& P. J. Di Maggio, 143-163. Chicago: University of Chicago Press.

Jick, T. D. (1979). Mixing Qualitative and Quantitative Methods: Triangulation in Action. Administrative Science Quarterly, 24(4), 602-611.

Johnston, S., \& Selsky, J. W. (2006). Duality and Paradox: Trust and Duplicity in Japanese Business Practice. Organization Studies, 27(2), 183-205.

Jones, G. R., \& George, J. M. (1998). The Experience of Evolution of Trust: Implications for Cooperation and Teamwork. Academy of Management Review, 23(3), 531-546.

Kahneman, D., Slovic, P., \& Tversky, A. (1982). Judgment under Uncertainty: Heuristics and Biases. Cambridge: Cambridge University Press.

Kautonen, T., Zolin, R., Kuckertz, A., \& Viljamaa, A. (2010). Ties that Blind? How Strong Ties Affect Small Business Owner-Managers' Perceived Trustworthiness of their Advisors. Entrepreneurship \& Regional Development, 22, 189-209.

Kibler, E., Fink, M., Lang, R., \& Muñoz, P. (2015). Place Attachment and Social Legitimacy: Revisiting the Sustainable Entrepreneurship Journey. Journal of Business Venturing Insights, 3(2), 24-29.

Korsgaard, C. (1996). Creating the Kingdom of Ends. Cambridge: Cambridge University Press.

Krishna, A. (2002). Active Social Capital: Tracing the Roots of Development and Democracy. New York.: Columbia University Press.

Lang, R., Kibler, E., \& Fink, M. (2013). Understanding Place-Based Entrepreneurship in Rural Central Europe - A Comparative Institutional Analysis. International Small Business Journal, 32(2), 204-227.

Lewicki, R. J., \& Bunker, B. B. (1996). Developing and Maintaining Trust in Work 
Relationships. In R. R. Kramer \& T. R. Tyler (Eds.), Trust in Organisations: Frontiers of Theory and Research (p. 114-139). Thousands Oaks, CA: SAGE Publications Inc. Lewicki, R. J., \& Wiethoff, C. (2000). Trust, Trust Development and Trust Repair. In D. Morton \& C. P.T. (Eds.), The Handbook of Conflict Resolution (p. 86-107). San Francisco, CA: Jossey Bass.

Li, P. P. (2007). Towards an Interdisciplinary Conceptualization of Trust: A Typological Approach. Management and Organization Review, 3(3), 421-445.

Lieblich, A., Tuval-Mashiach, R., \& Zilber, T. (1998). Narrative Research: Reading, Analysis, and Interpretation (Vol. 47). Thousand Oaks, CA: Sage Publications. Luhmann, N. (2000). Familiarity, Confidence, Trust: Problems and Alternative. In Trust: Making and Breaking Cooperative Relations, edited by D. Gambetta, 94-107. Oxford: Department of Sociology - University of Oxford.

Mathews, M., \& Stokes, P. (2013). The Creation of Trust: The Interplay of Rationality, Institutions and Exchange. Entrepreneurship \& Regional Development, 25, 845-866. Mayer, R. C., \& Davies, J. A. (1999). The Effect of the Performance Appraisal System on Trust for Management: A Field Quasi-Experiment. Journal of Applied Psychology, 84(1), 123-136.

Mayer, R. C., Davies, J. A., \& Schoorman, F. D. (1995). An Integrative Model of Organisational Trust. Academy of Management Review, 20(3), 709-734.

Mayring, P. (2008). Qualitative Inhaltsanalyse: Grundlagen und Techniken. WeinheimBasel.: Beltz.

McAllister, D. J. (1995). Affect- and Cognition-Based Trust as a Foundation for Interorganisational Cooperation in Organisations. Academy of Management Journal, $38(1), 24-59$.

McEvily, B., \& Tortoriello, M. (2011). Measuring Trust in Organizational Research: Review 
and Recommendations. Journal of Trust Research, 1(1), 23-63.

Meccheri, N., \& Pelloni, G. (2006). Rural Entrepreneurs and Institutional Assistance: An Empirical Study from Mountains Italy. Entrepreneurship \& Regional Development, 18(5), 371-392.

Medda-Windischer, A., \& Carlà, A. (2013). Migration and Cohabitation in South Tyrol. European Social Fund.

Meyer, J. W., \& Rowan, B. (1977). Institutionalized Organizations - Formal Structure as Myth and Ceremony. American Journal of Sociology, 83(2), 340-363.

Molina-Azorín, J. F., López-Gamero, M. D., Pereira-Molina, J., \& Pertusa-Ortega, E. M. (2012). Mixed Methods Studies in Entrepreneurship Research: Applications and Contributions. Entrepreneurship and Regional Development, 24, 425-456.

Möllering, G. (2001). The Nature of Trust: From Georg Simmel to a Theory of Expectation, Interpretation and Suspension. Sociology, 35(2), 403-420.

Moro, A., \& Fink, M. (2013). Loan Manager Trust and Credit Access for SMEs. Journal of Banking \& Finance, 37(3), 927-936.

Moro, A., Fink, M., \& Kautonen, T. (2014). How Do Banks Assess Entrepreneurial Competence? Public Data vs. Voluntary Information Disclosure. International Small Business Journal, 35(5), 525-544.

Moro, A., Maresch, D., \& Ferrando, A. (2016b). Creditor Protection, Judicial Enforcement and Credit Access. European Journal of Finance. doi:dx.doi.org/10.1080/1351847X.2016.1216871

Moro, A., Maresch, D., \& Fink, M. (2015). Reduction in Information Asymmetry and Credit Access for Small and Medium-Sized Enterprises. Journal of Financial Research, 38(1), $121-143$.

Morwood, J. (2005). Oxford Latin Desk Dictionary. Oxford: Oxford University Press. 
Moskowitz, T. J., \& Vissing-Jørgensen, A. (2002). The Returns to Entrepreneurial Investment: A Private Equity Premium Puzzle? The American Economic Review, 92(4), $745-778$.

Moulaert, F., \& Nussbaumer, J. (2005). Defining the Social Economy and its Governance at the Neighbourhood Level: A Methodological Reflection. Urban Studies, 42(11), 20712088.

Muthusamy, S. K., \& White, M. A. (2005). Learning and Knowledge Transfer in Strategic Alliances: A Social Exchange View. Organization Studies, 26(3), 415-441.

Nooteboom, B. (2002). Trust. Cheltenham: Edward Elgar Publishing Inc.

Nunnally, J. (1967). Psychometric Theory. New York, NY: McGraw-Hill.

Oba, B., \& Semerciöz, F. (2005). Antecedents of Trust in Industrial Districts: An Empirical Analysis of Inter-Firm Relations in a Turkish Industrial District. Entrepreneurship and Regional Development, 17, 163-182.

Patzelt, H., \& Shepherd, D. A. (2008). The Decision to Persist with Underperforming Alliances: The Role of Trust and Control. Journal of Management Studies, 45(7), 12171243.

Ramstad, Y. (1986). A Pragmatist's Quest for Holistic Knowledge: The Scientific Methodology of John R. Commons. Journal of Economic Issues, 20(4), 1067-1105.

Rheinbaben, J. von, \& Ruckes, M. (2004). The Number and the Closeness of Bank Relationships. Journal of Banking \& Finance, 28, 1597-1615.

Richardson, T., \& Jensen, O. (2003). Linking Discourse and Space: Towards a Cultural Sociology of Space in Analysing Spatial Policy Discourses. Urban Studies, 40(1), 7-22. Ring, P. S., \& Van de Ven, A. H. (1992). Structuring Cooperative Relationships Between Organisations. Strategic Management Journal, 13, 483-498.

Sayer, A. (1992). Method in Social Science: A Realist Approach. London: Routledge. 
Scott, J. A. (2006). Loan Officer Turnover and Credit Availability for Small Firms. Journal of Small Business Management, 44(4), 544-562.

Scott, W. R. (1995). Institutions and Organizations. Thousand Oaks, CA: Sage.

Scott, W. R. (2010). Reflections: The Past and Future of Research on Institutions and Institutional Change. Journal of Change Management, 10(1), 5-21.

Searle, J. R. (1990). Collective Intentions and Actions. In Intentions in Communication, edited by P. R. Cohen, J. Morgan, \& M. E. Pollack., 401-416. Cambridge, MA: Harvard Business School Press.

Shapiro, S. P. (1987). The Social Control of Impersonal Trust. American Journal of Sociology, 93(3), 623-658.

Sharpe, S. A. (1990). Asymmetric Information, Bank Lending, and Implicit Contracts: A Stylized Model of Customer Relationships. Journal of Finance, 45(4), 1069-1087.

Stein, J. C. (2002). Information Production and Capital Allocation: Decentralised versus Hierarchical Firms. Journal of Finance, 57(5), 1891-1921.

Strätling, R., Wijbenga, F. H., \& Dietz, G. (2013). The Impact of Contracts on Trust in Entrepreneur-Venture Capitalist Relationships. International Small Business Journal, $30(8), 811-831$.

Sugden, R., \& Hollis, M. (1993). Rationality in Action. Mind, 102, 1-35.

Thorgren, S., \& Wincent, J. (2011). Interorganizational Trust: Origins, Dysfunctions and Regulation of Rigidities. British Journal of Management, 22(1), 21-41.

Thornton, P. H., \& Flynn, K. H. (2003). Entrepreneurship, Networks, and Geographies. In Handbook of Entrepreneurship Research, edited by Z. Acs \& Audretsch, D., 401-433. New York: Kluwer.

Tillmar, M. (2006). Swedish Tribalism and Tanzanian Entrepreneurship: Preconditions for Trust Formation. Entrepreneurship and Regional Development, 18, 91-107. 
Tinsley, D. B. (1996). Trust Plus Capabilities. Academy of Management Review, 21(2), 335337.

Wathne, K. H., \& Heide, J. B. (2000). Opportunism in Interfirm Relationship: Forms, Outcomes, and Solutions. Journal of Marketing, 64(4), 36-51.

Welter, F. (2011). Contextualizing Entrepreneurship-Conceptual Challenges and Ways Forward. Entrepreneurship Theory and Practice, 35(1), 165-184.

Welter, F. (2012). All You Need is Trust? A Critical Review of the Trust and Entrepreneurship Literature. International Small Business Journal, 30(4), 193-212.

Welter, F., \& Kautonen, T. (2005). Trust, Social Networks and Enterprise Development: Exploring Evidence from East and West Germany. International Entrepreneurship and Management Journal, 1(3), 367-379.

Welter, F., Kautonen, T., Chepurenko, A., Malieva, E., \& Venasaar, U. (2004). Trust Environments and Entrepreneurial Behavior - Exploratory Evidence from Estonia, Germany and Russia. Journal of Enterprising Culture 12(4), 327-349.

Welter, F., \& Trettin, L. (2011). Challenges for Spatially Oriented Entrepreneurship Research. Entrepreneurship and Regional Development, 23(7-8), 575-602.

Williams, M. (2001). In Whom We Trust: Group Membership as an Affective Context for Trust Development. Academy of Management Review, 26(3), 377-396.

Yin, R. K. (2009). Case Study Research: Design and Methods (Vol. 4). Thousand Oak: Sage. Zheng, X., Sadok El Ghoul, S., Guedhami, O., \& Kwok, C. Y. C. (2012). National Culture and Corporate Debt Maturity. Journal of Banking \& Finance, 36(2), 468-488. 
Table 1 - Interview Data and Derivation of Hypotheses

\section{Code Quotation from interviews}

Q1 "The local community faces a relatively high turnover and many customers are quite new to the area."

Aspect

Hypothesis

Friuli

Q2 "I have known the large majority of the population in the area since I was a child." local Red Cross."

"I spend my entire working day here but I live in a town 45 kilometres away. I guess I miss some relevant information about what happens around here."

Q5 "I wish I could trust my customers more but sometimes they are totally new to me and to the area: how can you trust them?"

Q6 "I was born here. I spent my childhood with many of the bank customers."

"I do not rely on official facts and figures. You know they are affected by the tax strategy. Asset value, work in progress,

Q7 inventory - all rubbish. They are always adjusted. You know there are costs and revenues that are not recorded in the books. Entrepreneurs disclose them if you exert some pressure but you have no proof."

"You gain information about your client from other customers. They inform you whether he is honest in his business relationships, his capabilities, etc."

Q9 "The credit scoring system decides whether to provide credit to the customer."

Q10 "I have a lot of room for manoeuvre. In addition, when I cannot decide whether to give credit I can always discuss things face-to-face with whoever is in charge of making the decision."

Q11 "For larger amounts, the decision is taken centrally. I have to send out all the documents but I do not know who is in charge of making the decision."

Q12 "I typically share my opinion about the customer with the director."
South Tyrol

H1: The positive effect of loan managers' trust in the entrepreneur on the overall amount of credit is sensitive to the normative institutional environment prevailing in the region.

Friuli

South Tyrol

Small bank

Small bank

Large bank

Small bank

Large bank

Small bank
H2: The positive effect of loan managers' trust in the entrepreneur on the overall amount of credit is sensitive to the regulative institutional environment prevailing in the banking organisation. 
Table 2 - Factor Analysis of Trust Items

\begin{tabular}{|c|c|c|c|c|c|}
\hline Variable & Description & Mean & Std. Dev. & $\begin{array}{r}\text { Factor } \\
\text { Trust }\end{array}$ & Uniqueness \\
\hline benevolence (ben1) & $\begin{array}{l}\text { The entrepreneur adapts his } \\
\text { interests to suit those of } \\
\text { commercial partners. }\end{array}$ & 3.7812 & 0.6948 & 0.7900 & 0.3759 \\
\hline benevolence (ben2) & $\begin{array}{l}\text { The entrepreneur pays attention to } \\
\text { the needs of the employees. }\end{array}$ & 3.5405 & 0.7485 & 0.7226 & 0.4779 \\
\hline benevolence (ben3) & $\begin{array}{l}\text { The entrepreneur is very involved } \\
\text { in the community. }\end{array}$ & 3.0853 & 1.1695 & & \\
\hline integrity (int1) & $\begin{array}{l}\text { The entrepreneur is totally honest } \\
\text { in negotiations with commercial } \\
\text { partners. }\end{array}$ & 3.8753 & 0.7223 & 0.7561 & 0.4282 \\
\hline integrity (int2) & $\begin{array}{l}\text { The entrepreneur is consistent in } \\
\text { his decisions and behaviour. }\end{array}$ & 3.8096 & 0.6921 & 0.7616 & 0.4200 \\
\hline integrity (int3) & $\begin{array}{l}\text { Would you be happy to } \\
\text { recommend to a female friend that } \\
\text { she should work at the firm? }\end{array}$ & 3.4354 & 0.9509 & 0.7369 & 0.4570 \\
\hline
\end{tabular}


Table 3 - Descriptive Statistics

\begin{tabular}{|c|c|c|c|c|c|c|c|c|c|c|c|c|c|c|c|c|c|}
\hline Code & Description & Mean & Std. Dev. & Min & Max & 1 & 2 & 3 & 4 & 5 & 6 & 7 & 8 & 9 & 10 & 11 & 12 \\
\hline LN_TOT_DEBT $^{1}$ & Overall amount of credit $^{2}$ & 529,552 & $1,053,752$ & 5,0001 & $14,400,000$ & 1.000 & & & & & & & & & & & \\
\hline FIRM_COLL & Firm collateral (dummy) & 0.2500 & 0.433 & 0 & 1.000 & 0.298 & 1.000 & & & & & & & & & & \\
\hline PERS_COLL & Private collateral (dummy) & 0.8110 & 0.392 & 0 & 1.000 & 0.058 & 0.041 & 1.000 & & & & & & & & & \\
\hline CL_INDEX & $\begin{array}{l}\text { Expected contraction in credit } \\
\text { provided (Bank of Italy index) }\end{array}$ & 0.0598 & 0.053 & 0 & 0.700 & -0.021 & 0.050 & -0.050 & 1.000 & & & & & & & & \\
\hline LN_TURNOVER $^{1}$ & Turnover $^{2}$ & $2,205,061$ & $4,629,894$ & 13,0004 & $46,900,000$ & 0.266 & 0.018 & 0.015 & -0.113 & 1.000 & & & & & & & \\
\hline ROS & Return on sales & 0.0505 & 0.091 & -0.528 & 0.470 & -0.026 & -0.042 & -0.028 & -0.154 & -0.072 & 1.000 & & & & & & \\
\hline ASS/TURN & Assets/Turnover & 1.4905 & 3.594 & .1100 & 42.467 & -0.043 & 0.107 & -0.063 & 0.298 & -0.163 & 0.100 & 1.000 & & & & & \\
\hline FREQ_REV & Frequency of reviewing & 2.0416 & 0.483 & 1.000 & 3.000 & 0.322 & 0.204 & 0.080 & -0.301 & 0.128 & 0.021 & -0.018 & 1.000 & & & & \\
\hline FREQ_MEET & Frequency of meetings & 2.9540 & 1.227 & 1.000 & 4.000 & 0.097 & 0.182 & 0.004 & 0.122 & -0.013 & -0.059 & 0.035 & 0.246 & 1.000 & & & \\
\hline BANK_EMP & $\begin{array}{l}\text { Number of bank employees } \\
\text { involved in the relationship }\end{array}$ & 1.5885 & 1.155 & 1.000 & 7.000 & 0.005 & 0.010 & 0.029 & 0.140 & -0.111 & 0.102 & 0.011 & -0.124 & -0.104 & 1.000 & & \\
\hline BANK_SIZE & Bank size (small, 0, large, 1) & 0.1860 & 0.390 & 01 & 1.000 & -0.162 & -0.065 & 0.013 & 0.090 & -0.088 & -0.057 & 0.025 & -0.080 & 0.159 & -0.234 & 1.000 & \\
\hline REGION & $\begin{array}{l}\text { Region (0: South Tyrol; } 1 \text { : } \\
\text { Friuli) }\end{array}$ & 0.3282 & 0.470 & 0 & 1.000 & -0.131 & -0.045 & -0.010 & 0.432 & -0.086 & -0.040 & 0.014 & -0.075 & 0.196 & -0.219 & 0.681 & 1.000 \\
\hline TRUST & Trust (benevolence + integrity) & 0.0000 & 1.000 & -4.388 & 2.286 & 0.095 & 0.009 & -0.085 & 0.022 & 0.088 & -0.014 & 0.023 & 0.050 & 0.081 & 0.037 & 0.017 & -0.023 \\
\hline
\end{tabular}

${ }^{1}$ The values reported in the descriptive statistics are the original ones. In the regression, the logarithms of the variables have been entered.

${ }^{2}$ These values are expressed in Euros. 


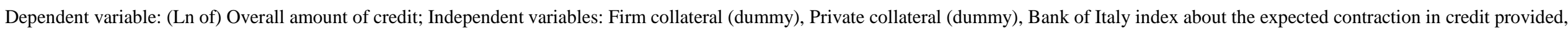

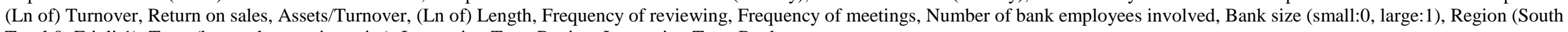
Tyrol:0; Friuli:1), Trust (benevolence + integrity), Interaction Trust Region, Interaction Trust Bank.

\begin{tabular}{|c|c|c|c|c|c|c|c|c|c|c|c|c|c|c|c|c|c|c|c|}
\hline & & \multicolumn{6}{|c|}{ Overall Sample } & \multicolumn{6}{|c|}{ Sample Split by Region } & \multicolumn{6}{|c|}{ Sample Split by Bank Size } \\
\hline & & \multicolumn{3}{|c|}{ Starting Model } & \multicolumn{3}{|c|}{ Interaction Model } & \multicolumn{3}{|c|}{ South Tyrol Banks } & \multicolumn{3}{|c|}{ Friuli Banks } & \multicolumn{3}{|c|}{ Small Banks } & \multicolumn{3}{|c|}{ Large Banks } \\
\hline & & \multicolumn{2}{|c|}{ Number of obs } & 450 & \multicolumn{2}{|l|}{ Number of obs } & 450 & \multicolumn{2}{|c|}{ Number of obs } & 302 & \multicolumn{2}{|c|}{ Number of obs } & 148 & \multicolumn{2}{|l|}{ Number of obs } & \multirow{2}{*}{$\begin{array}{r}366 \\
23.96\end{array}$} & \multicolumn{2}{|l|}{ Number of obs } & \multirow{2}{*}{$\begin{array}{r}84 \\
11.9\end{array}$} \\
\hline & & $\mathrm{F}(13,436)$ & & 28.46 & $\mathrm{~F}(15,434)$ & & 24.83 & $\mathrm{~F}(11,290)$ & & 23.15 & $\mathrm{~F}(12,135)$ & & 18.56 & $\mathrm{~F}(12,353)$ & & & $F(10,73)$ & & \\
\hline & & Prob > F & & 0.0000 & Prob $>\mathrm{F}$ & & 0.0000 & Prob $>$ F & & 0.0000 & Prob $>$ F & & 0.0000 & Prob $>F$ & & 0.0000 & Prob $>$ F & & 0.0000 \\
\hline & & R-squared & & 0.4245 & R-squared & & 0.4248 & R-squared & & 0.4035 & R-squared & & 0.5854 & R-squared & & 0.3978 & R-squared & & 0.5453 \\
\hline & & Root MSE & & 1.0417 & Root MSE & & 1.0439 & Root MSE & & 1.1354 & Root MSE & & 0.75314 & Root MSE & & 1.1013 & Root MSE & & 0.67526 \\
\hline Variable & Code & Coef. & $\begin{array}{c}\text { Robust } \\
\text { Std. Errors }\end{array}$ & $\mathbf{P}>\mathbf{t}$ & Coef. & $\begin{array}{l}\text { Robust Std. } \\
\text { Errors }\end{array}$ & $\mathbf{P}>\mathbf{t}$ & Coef. & $\begin{array}{c}\text { Robust } \\
\text { Std. Errors }\end{array}$ & $\mathbf{P}>\mathbf{t}$ & Coef. & $\begin{array}{c}\text { Robust } \\
\text { Std. Errors }\end{array}$ & Coef. & Coef. & $\begin{array}{c}\text { Robust } \\
\text { Std. } \\
\text { Errors } \\
\end{array}$ & Coef. & Coef. & $\begin{array}{c}\text { Robust } \\
\text { Std. } \\
\text { Errors }\end{array}$ & Coef. \\
\hline Firm collateral (dummy) & FIRM_COLL & 1.0371 & 0.1078 & ${ }^{* * *}$ & 1.0312 & 0.1077 & $* * *$ & 1.1888 & 0.1375 & $* * *$ & 0.7397 & 0.1595 & $* * *$ & 1.0999 & 0.1253 & *** & 0.8782 & 0.2006 & *** \\
\hline Private collateral (dummy) & PERS_COLL & 0.0213 & 0.1294 & & 0.0206 & 0.1307 & & 0.2083 & 0.1728 & & -0.2643 & 0.1622 & & 0.0882 & 0.1520 & & -0.0473 & 0.2184 & \\
\hline Expected contraction in credit provided & CL_INDEX & 7.4648 & 1.7008 & $* * *$ & 7.4851 & 1.7068 & $* * *$ & 7.8896 & 2.5146 & $* * *$ & 7.5336 & 2.0591 & *** & 7.8746 & 1.7848 & *** & & (omitted) & \\
\hline Turnover (natural logarithm) & LN_TURNOVER & 0.3533 & 0.0404 & $* * *$ & 0.3531 & 0.0405 & $* * *$ & 0.3083 & 0.0528 & $* * *$ & 0.4850 & 0.0535 & *** & 0.3309 & 0.0476 & *** & 0.4783 & 0.0588 & *** \\
\hline Return on sales & ROS & 0.1239 & 0.4054 & & 0.0967 & 0.4105 & & 0.3183 & 0.7041 & & -0.7231 & 0.5504 & $* * *$ & 0.3153 & 0.5758 & & -1.1855 & 0.6298 & $* * *$ \\
\hline Assets/Turnover & ASSTTURN & -0.0016 & 0.0151 & & -0.0019 & 0.0151 & & -0.0112 & 0.0194 & & 0.1884 & 0.0408 & & -0.0087 & 0.0146 & & 0.2227 & 0.0561 & \\
\hline Length (natural logarithm) & LN_LENGTH & -0.0193 & 0.0652 & & -0.0192 & 0.0652 & & 0.0139 & 0.0812 & & -0.1182 & 0.1067 & & 0.0079 & 0.0765 & & -0.1539 & 0.1098 & \\
\hline Frequency of reviewing & FREQ_REV & 0.9194 & 0.1313 & *** & 0.9238 & 0.1320 & $* * *$ & 0.9541 & 0.1645 & $* * *$ & 0.5585 & 0.1912 & *** & 0.9378 & 0.1484 & *** & 0.6946 & 0.2477 & *** \\
\hline Frequency of meetings & FREQ_MEET & 0.0721 & 0.0460 & & 0.0731 & 0.0462 & & 0.0780 & 0.0625 & & 0.0608 & 0.0555 & & 0.0650 & 0.0529 & & 0.0833 & 0.0735 & \\
\hline Number of bank employ ees involved & BANK_EMP & 0.0331 & 0.0497 & & 0.0347 & 0.0500 & & 0.0136 & 0.0532 & & 0.1649 & 0.1463 & & 0.0216 & 0.0508 & & -0.0720 & 0.6734 & \\
\hline Bank size (small:0, large:1) & BANK_SIZE & -0.2334 & 0.1663 & ${ }^{* * *}$ & -0.2387 & 0.1722 & & & (omitted) & & -0.2480 & 0.1993 & & & & & & & \\
\hline Region (South Tyrol:0; Friuli:1) & REGION & -0.4346 & 0.1711 & ** & -0.4321 & 0.1763 & ** & & & & & & & -0.4646 & 0.1764 & *** & & (omitted) & \\
\hline Trust (benevolence + integrity) & TRUST & 0.1463 & 0.0488 & $* * *$ & 0.1341 & 0.0566 & ** & 0.1471 & 0.0595 & ** & 0.1448 & 0.0908 & & 0.1519 & 0.0552 & *** & 0.1155 & 0.0922 & \\
\hline Interaction Trust Region & TRUST_REG & & & & 0.0446 & 0.1435 & & & & & & & & & & & & & \\
\hline Interaction Trust Bank & TRUST_BANK & & & & 0.0027 & 0.1649 & & & & & & & & & & & & & \\
\hline Constant & _cons & 4.7672 & 0.6675 & $* * *$ & 4.7584 & 0.6702 & $* * *$ & 5.0571 & 0.8559 & $* * *$ & 3.4746 & 0.9809 & *** & 4.9315 & 0.7671 & *** & 3.5754 & 1.2159 & *** \\
\hline \begin{tabular}{|l|} 
Highest VIF \\
\end{tabular} & & Region & & 3.92 & Region & & 3.97 & Cl_index & & 3.86 & Bank Size & & 2.08 & \begin{tabular}{|l|} 
Cl_index \\
\end{tabular} & & 3.59 & ROS & & 1.43 \\
\hline Mean VIF & & & & 1.76 & & & 1.86 & & & 1.66 & & & 1.36 & & & 1.57 & & & 1.23 \\
\hline
\end{tabular}

$*<.10$

$* *<.05$

$* * *<.01$ 


\section{Table 5 - Instrumented regressions}

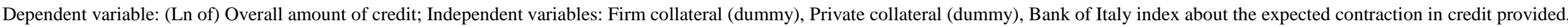

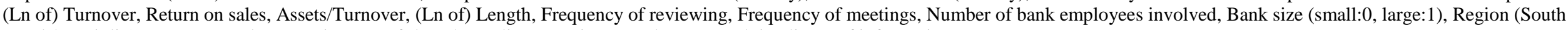
Tyrol:0; Friuli:1), Instrumented Trust using (Ln of) length, quality, quantity, completeness and timeliness of information.

\begin{tabular}{|c|c|c|c|c|c|c|c|c|c|c|c|c|c|c|c|c|}
\hline & & \multirow{2}{*}{\multicolumn{3}{|c|}{$\begin{array}{c}\text { Overall Sample } \\
\text { Starting Model }\end{array}$}} & \multicolumn{6}{|c|}{ Sample Split by Region } & \multicolumn{6}{|c|}{ Sample Split by Bank Size } \\
\hline & & & & & \multicolumn{3}{|c|}{ South Tyrol Banks } & \multicolumn{3}{|c|}{ Friuli Banks } & \multicolumn{3}{|c|}{ Small Banks } & \multicolumn{3}{|c|}{ Large Banks } \\
\hline & & Number of $\mathrm{c}$ & & 449 & Number of o & & 301 & Number of o & & 148 & Number of $\mathrm{o}$ & & 365 & Number of obs & & \\
\hline & & Wald chi2 21 & & 382.76 & Wald chi2 $(11$ & & 266.14 & Wald chi2 $(12$ & & 244 & Wald chi2 $(12$ & & 299.97 & Wald chi2(10) & & 128.99 \\
\hline & & Prob > chi 2 & & 0.0000 & Prob > chi 2 & & 0.0000 & Prob > chi2 & & 0.0000 & Prob > chi2 & & 0.0000 & Prob > chi 2 & & 0.0000 \\
\hline & & R-squared & & 0.4226 & R-squared & & 0.4016 & R-squared & & 0.5841 & R-squared & & 0.3964 & R-squared & & 0.537 \\
\hline & & Root MSE & & 1.0259 & Root MSE & & 1.1133 & Root MSE & & 0.7204 & Root MSE & & 1.0818 & Root MSE & & 0.6352 \\
\hline Variable & Code & Coef. & $\begin{array}{c}\text { Robust } \\
\text { Std. Errors }\end{array}$ & $\mathbf{P}>\mathbf{t}$ & Coef. & $\begin{array}{c}\text { Robust } \\
\text { Std. Errors }\end{array}$ & $\mathbf{P}>\mathbf{t}$ & Coef. & $\begin{array}{c}\text { Robust } \\
\text { S td. Errors }\end{array}$ & $\mathbf{P}>\mathbf{t}$ & Coef. & $\begin{array}{c}\text { Robust } \\
\text { Std. Errors }\end{array}$ & $\mathbf{P}>\mathbf{t}$ & Coef. & $\begin{array}{c}\text { Robust } \\
\text { Std. Errors }\end{array}$ & $\mathbf{P}>\mathbf{t}$ \\
\hline Instrumented Trust & I_TRUST & 0.1117 & 0.0731 & & 0.1244 & 0.0971 & & 0.0994 & 0.1129 & & 0.1417 & 0.0850 & & 0.0094 & 0.1341 & \\
\hline Firm collateral (dummy) & FIRM_COLL & 1.0275 & 0.1060 & $* * *$ & 1.1723 & 0.1367 & $* * *$ & 0.7570 & 0.1532 & *** & 1.0904 & 0.1235 & $* * *$ & 0.9046 & 0.1893 & *** \\
\hline Private collateral (dummy) & PERS_COLL & 0.0265 & 0.1300 & & 0.2198 & 0.1744 & & -0.2718 & 0.1569 & & 0.1003 & 0.1531 & & -0.0379 & 0.2055 & \\
\hline Expected contraction in credit provided & CL_INDEX & 7.5967 & 1.6703 & $* * *$ & 8.1347 & 2.4672 & $* * *$ & 7.5558 & 1.9781 & *** & 7.9782 & 1.7506 & $* * *$ & & (omitted) & *** \\
\hline Turnover (natural logarithm) & LN_TURNOVER & 0.3581 & 0.0404 & $* * *$ & 0.3133 & 0.0524 & $* * *$ & 0.4896 & 0.0512 & *** & 0.3346 & 0.0476 & $* * *$ & 0.4804 & 0.0550 & *** \\
\hline Return on sales & ROS & 0.1322 & 0.3967 & & 0.3006 & 0.7029 & & -0.6965 & 0.5112 & & 0.3184 & 0.5708 & & -1.1306 & 0.5459 & \\
\hline Assets/Turnover & ASS/T URN & -0.0022 & 0.0148 & & -0.0127 & 0.0190 & & 0.1907 & 0.0383 & *** & -0.0092 & 0.0143 & & 0.2315 & 0.0529 & *** \\
\hline Length (natural logarithm) & LN_LENGTH & -0.0144 & 0.0650 & & 0.0162 & 0.0813 & & -0.1110 & 0.1031 & & 0.0080 & 0.0761 & & -0.1332 & 0.1076 & \\
\hline Frequency of reviewing & FREQ_REV & 0.9152 & 0.1293 & $* * *$ & 0.9548 & 0.1623 & $* * *$ & 0.5444 & 0.1814 & *** & 0.9326 & 0.1465 & $* * *$ & 0.6634 & 0.2331 & *** \\
\hline Frequency of meetings & FREQ_MEET & 0.0732 & 0.0455 & & 0.0776 & 0.0614 & & 0.0578 & 0.0536 & & 0.0647 & 0.0522 & & 0.0751 & 0.0710 & \\
\hline Number of bank employees involved & BANK_EMP & 0.0360 & 0.0495 & & 0.0154 & 0.0535 & & 0.1513 & 0.1445 & & 0.0229 & 0.0508 & & -0.1923 & 0.6587 & \\
\hline Bank size (small:0, large:1) & BANK_SIZE & -0.2141 & 0.1653 & & & (omitted) & & -0.2363 & 0.1901 & & & & & & & \\
\hline Region (South Tyrol:0; Friuli:1) & REGION & -0.4479 & 0.1683 & $* * *$ & & & & & & & -0.4719 & 0.1735 & $* * *$ & & (omitted) & \\
\hline Constant & _cons & 4.6812 & 0.6704 & $* * *$ & 4.9643 & 0.8632 & $* * *$ & 3.4425 & 0.9429 & *** & 4.8750 & 0.7739 & $* * *$ & 3.7141 & 1.1744 & *** \\
\hline
\end{tabular}

$*<10$

$* *<.05$

$* * *<.01$ 